\title{
Negative regulation between the expression levels of receptor for hyaluronic acid-mediated motility and hyaluronan leads to cell migration in pancreatic cancer
}

\author{
XIAO-BO CHENG ${ }^{1 *}$, SHUWEN WANG ${ }^{1 *}$, HUA YANG $^{1}$, HANXING TONG $^{2}$, GUODONG SHI $^{1}$, LILI WU $^{3}$, \\ JIAN ZHOU ${ }^{1}$, LEI SHI ${ }^{1}$, HONGWEI LI ${ }^{1}$, SONGTAO REN ${ }^{1}$, YUHONG ZHOU ${ }^{4}$ and NORIHIRO SATO ${ }^{5}$ \\ ${ }^{1}$ Shanghai Public Health Clinical Center, Fudan University, Shanghai 201508; Departments of ${ }^{2}$ General Surgery, \\ ${ }^{3}$ Radiotherapy and ${ }^{4}$ Medical Oncology, Zhongshan Hospital, Fudan University, Shanghai 200032, P.R. China; \\ ${ }^{5}$ Department of Surgery 1, School of Medicine, University of Occupational and \\ Environmental Health, Kitakyushu, Fukuoka 807-8555, Japan
}

Received February 15, 2019; Accepted July 22, 2020

DOI: $10.3892 / \mathrm{ol} .2020 .12060$

\begin{abstract}
Receptor for hyaluronic acid(HA)-mediated motility (RHAMM) expression is upregulated in pancreatic ductal adenocarcinoma (PDAC). In the present study, small interfering RNA knockdown was used to investigate the regulatory mechanism and function of RHAMM in PDAC cells. Reverse transcription-quantitative PCR was used to measure the mRNA expression levels of RHAMM, hyaluronan synthases (HAS1, HAS2 and HAS3) and hyaluronidases (HYAL1, HYAL2 and HYAL3) in eight PDAC cell lines. Cell migration was assessed using a Transwell assay, while HA concentration was measured using an ELISA. The results revealed that RHAMM-knockdown significantly increased migration in two PDAC cell lines, significantly decreased migration in one cell line and did not affect migration in the other cell lines, and was positively associated with changes in HA production. There was a linear negative correlation between RHAMM
\end{abstract}

Correspondence to: Dr Norihiro Sato, Department of Surgery 1, School of Medicine, University of Occupational and Environmental Health, Iseigaoka 1-1, Yahatanishi Ku, Kitakyushu, Fukuoka 807-8555, Japan

E-mail: norisato@med.uoeh-u.ac.jp

Professor Yuhong Zhou, Department of Medical Oncology, Zhongshan Hospital, Fudan University, 180 Fenglin Road, Shanghai 200032, P.R. China

E-mail: zhou.yuhong@zs-hospital.sh.cn

*Contributed equally

Abbreviations: RHAMM, receptor for hyaluronic acid-mediated motility; HA, hyaluronic acid; PDAC, pancreatic ductal adenocarcinoma; HAS, HA synthase; HYAL, hyaluronidases; HMW-HA, high-molecular weight HA; 4-MU, 4-methylumbelliferone; TPA, 12-O-tetradecanoyl-phorbol-13-acetate

Key words: RHAMM-knockdown, PDAC, HA, HAS, HYAL
mRNA expression and HA concentration in PDAC cells and tissues. The negative correlation between RHAMM mRNA expression and HA concentration was demonstrated in other models, including SUIT2 cells treated with an HA inhibitor or stimulator and a system involving co-culture of SUIT2 cells and stromal fibroblasts. The present findings demonstrated a negative correlation between RHAMM mRNA expression and HA production in a subset of PDAC cell lines. The efficacy of a therapeutic strategy targeting RHAMM should be carefully evaluated in future studies.

\section{Introduction}

Pancreatic ductal adenocarcinoma (PDAC) is an aggressive and lethal neoplasm, with a 5-year survival rate $<5 \%$ in the United States $(1,2)$. The typical pathological characteristics of pancreatic cancer are rapid invasion into the surrounding vascular, perineural and lymphatic systems, and frequent metastasis to distant organs (3). These features lead to this disease being frequently diagnosed at an advanced stage, precluding the possibility of curative surgical resection $(2,3)$. Therefore, there is a critical need to develop effective therapies to prevent the invasion and metastasis of PDAC.

In PDAC, tumor cells are surrounded by a hyaluronan (HA)-rich stroma, also known as desmoplasia (3-5). HA is a large linear glycosaminoglycan of up to $10^{6}-10^{7} \mathrm{Da}$ in its native form that is produced by hyaluronan synthases (HASs) and degraded into smaller fragments by hyaluronidases (HYALs) (6). The high accumulation of HA occurs in numerous types of cancer, including PDAC, and $\mathrm{HA}$ serves a critical role in various cellular processes, including cell proliferation, migration, invasion, metastasis, angiogenesis and resistance to chemotherapeutic agents (4-6). Membrane-bound or free extracellular HA binds to CD44 and the receptor for HA-mediated motility (RHAMM), which alters the cellular physiology (6). The interaction between $\mathrm{HA}$ and these two receptors induces CD44 receptor clustering and activates intracellular RHAMM-regulated 
MAPK, leading to ERK phosphorylation and activation of the transcription effectors activator protein-1 and $\mathrm{NF \kappa B}$, resulting in cell migration (6).

High CD44 expression is associated with a poor prognosis in patients with PDAC, and its knockdown inhibits the migration of PDAC cells (7). In our previous study, it was demonstrated that RHAMM is upregulated in PDAC cells and tissues, and is associated with a poor prognosis in patients with PDAC following surgical resection (8). Previously, RHAMM has been used as a promising target for antibody therapy to inhibit the extracellular function of RHAMM on the surface of cancer cells (9). Therefore, the present study hypothesized that the migration of PDAC cells may decrease following inhibition of RHAMM. To test this hypothesis, small interfering (si)RNA knockdown was used to determine the effects of RHAMM on the migratory ability of PDAC cells.

\section{Materials and methods}

Cell lines and reagents. A total of eight PDAC cell lines were used in the present study. BxPC-3, Panc-1, Capan-2, CFPAC1 and AsPC-1 were purchased from American Type Culture Collection, NOR-P1 from the RIKEN BioResource Center, and SUIT-2 and KP-2 from the Japanese Collection of Research Bioresources Cell Bank. The characteristics of the eight PDAC cell lines are shown in Table I. These cell lines had recently been obtained when the experiments were performed and their identities were routinely monitored by short tandem repeat profiling. Primary fibroblasts (sk-f2) derived from PDAC tissues were donated by Kyushu University (Fukuoka, Japan). PDAC cell lines and sk-f2 cells were maintained in RPMI-1640 medium supplemented with 10\% FBS and 1\% streptomycin and penicillin (all Thermo Fisher Scientific, Inc.) in a $5 \% \mathrm{CO}_{2}$ incubator at $37^{\circ} \mathrm{C}$. 4-methylumbelliferone (4-MU) and 12-O-tetradecanoyl-phorbol-13-acetate (TPA) were purchased from Sigma-Aldrich (Merck KGaA).

Tissue samples. Patients aged $\geq 18$ years old with histologically confirmed PDAC diagnosed and a Karnofsky Performance Score $\geq 80$ were enrolled. The main exclusion criteria were as follows: i) Central nervous system metastasis; and ii) other malignant tumors. Surgical tissue specimens (matched pairs of primary pancreatic tumor and adjacent non-tumor tissues, $1 \mathrm{~cm}$ away from the tumor tissue) collected from 20 patients with PDAC (11 men and 9 women; age range, 34-82 years; median age, 64 years) between August 2012 and December 2014 at the School of Medicine of the University of Occupational and Environmental Health (Kitakyushu, Japan) were evaluated by an experienced pathologist. All samples were collected and handled in an identical manner. Tissue aliquots were placed in RNAlater ${ }^{\circledR}$ Stabilization Solution (Ambion; Thermo Fisher Scientific, Inc.) at $-80^{\circ} \mathrm{C}$ until further use. The present study was approved by the Ethics Committee of the University of Occupational and Environmental Health (Kitakyushu, Japan), and written informed consent was obtained from all patients who approved the use of their tissues for unspecified research purposes.

Trypan blue dye exclusion (TBDE) assay of cell viability. The effects of RHAMM siRNA (100 nM), 4-MU (1,000 $\mu \mathrm{M})$ and
TPA (100 ng/ml) on cell viability were analyzed using TBDE assays as measurements of cytotoxicity. PDAC cells $\left(\sim 2 \times 10^{5}\right)$ were cultured at $37^{\circ} \mathrm{C}$ in the medium. The untreated and RHAMM siRNA-treated cells were harvested after $24 \mathrm{~h}$ of transfection, while the untreated, 4-MU- and TPA-treated cells were harvested after $48 \mathrm{~h}$ of treatment. Subsequently, $4 \%$ trypan blue was added at room temperature for $3 \mathrm{~min}$, and the cells were counted using a LUNA ${ }^{\mathrm{TM}}$ automated cell counter (Logos Biosystems, Inc.), according to the manufacturer's protocol. Cytotoxicity was determined from the number of viable cells (no color) in treated samples as a percentage of that in the untreated control.

siRNA targeting RHAMM. siRNA for RHAMM (ON-TARGETplus Human HMMR siRNA-SMARTpool L-010409-00-0005) and negative control siRNA (siGENOME Non-Targeting siRNA Pool D-001206-13-05) were purchased from Cytiva. All PDAC cell lines were transfected with $100 \mathrm{nM}$ siRNA using DhermaFECT 1 Transfection Reagent (Cytiva) for $24 \mathrm{~h}$ at $37^{\circ} \mathrm{C}$, according to the manufacturer's protocol. The target sequences were: GUUAACAGCCAGUGAGAUA [molecular weight (MW), 13,414.8 g/mol]; GGACUAAUG AACUACUAAA (MW, 13,384.8 g/mol); GAUACUACCUUG CCUGCUU (MW, 13,429.9 g/mol); CAAGUGGCGUCUCCU CUAU (MW, 13,444.8 g/mol).

Reverse transcription-quantitative $(R T-q) P C R$. Total RNA was isolated from all cells (untreated and treated) and tissues (matched pairs of primary pancreatic tumor and adjacent non-tumor tissues) using the RNeasy ${ }^{\circledR}$ Mini kit (Qiagen, Inc.). Single-stranded cDNA was synthesized from $1 \mu \mathrm{g}$ total RNA using the SuperScript ${ }^{\circledR}$ VILO $^{\text {TM }}$ MasterMix (Invitrogen; Thermo Fisher Scientific, Inc.) for $10 \mathrm{~min}$ at $25^{\circ} \mathrm{C}$, $1 \mathrm{~h}$ at $42^{\circ} \mathrm{C}$ and $5 \mathrm{~min}$ at $85^{\circ} \mathrm{C}$. mRNA expression analyses of RHAMM (Hs00234864_m1), HAS1 (Hs00758053_m1), HAS2 (Hs00193435_m1), HAS3 (Hs00193436_m1), HYAL1 (Hs00201046_m1), HYAL2 (Hs01117343_g1), HYAL3 (Hs00185910_m1) and the housekeeping gene GAPDH (Hs02758991_g1), used as a control, were performed using TaqMan ${ }^{\circledR}$ Fast Universal PCR Master Mix, TaqMan Gene Expression Assays and Step One Plus real-time PCR instrument (all Applied Biosystems; Thermo Fisher Scientific, Inc) at room temperature for $45 \mathrm{~min}$. The thermocycling conditions used for qPCR consisted of an initial denaturation step for $20 \mathrm{sec}$ at $95^{\circ} \mathrm{C}$, followed by 40 cycles of denaturation for $1 \mathrm{sec}$ at $95^{\circ} \mathrm{C}$, annealing for $20 \mathrm{sec}$ at $60^{\circ} \mathrm{C}$ and extension for $30 \mathrm{sec}$ at $72^{\circ} \mathrm{C}$. The relative quantification was performed using the comparative $2^{-\Delta \Delta \mathrm{Cq}}$ method (10).

Migration assay. After $24 \mathrm{~h}$ of treatment with siRNAs, the cells were harvested and counted, and $\sim 2 \times 10^{4}$ cells were seeded in $100 \mu \mathrm{l}$ medium with $1 \%$ FBS in the top chamber with an uncoated membrane (24-well Transwell insert; $8-\mu \mathrm{m}$ pore size; BD Biosciences). A total of $900 \mu \mathrm{l}$ medium containing $10 \%$ FBS was used as a chemoattractant in the lower chamber, and the cells were allowed to migrate at $37^{\circ} \mathrm{C}$ with $5 \% \mathrm{CO}_{2}$ for $48 \mathrm{~h}$. Non-migrating cells on the upper surface of the membrane were removed with a cotton swab. Migrating cells that penetrated onto the lower surface of the membrane were fixed with $70 \%$ methanol for $10 \mathrm{~min}$, stained with hematoxylin for $10 \mathrm{~min}$ and eosin for $5 \mathrm{~min}$, all at room temperature, and 
Table I. Characteristics of eight pancreatic ductal adenocarcinoma cell lines.

\begin{tabular}{llccc}
\hline Cell line & \multicolumn{1}{c}{ Derivation } & Metastasis & Proliferation, $h$ & Differentiation \\
\hline BxPC-3 & Primary tumor & No & $48-60$ & Moderate to poor \\
PANC-1 & Primary tumor & Yes & 52 & Poor \\
NOR-P1 & Liver metastasis & Yes & 16 & Poor \\
SUIT-2 & Liver metastasis & Yes & 38.2 & Moderate \\
KP-2 & Primary tumor & No & 48 & Moderate \\
Capan-2 & Primary tumor & No & 96 & Well \\
CFPAC-1 & Liver metastasis & Yes & 31 & Well \\
AsPC-1 & Ascites & Yes & $38-40$ & Poor \\
\hline
\end{tabular}
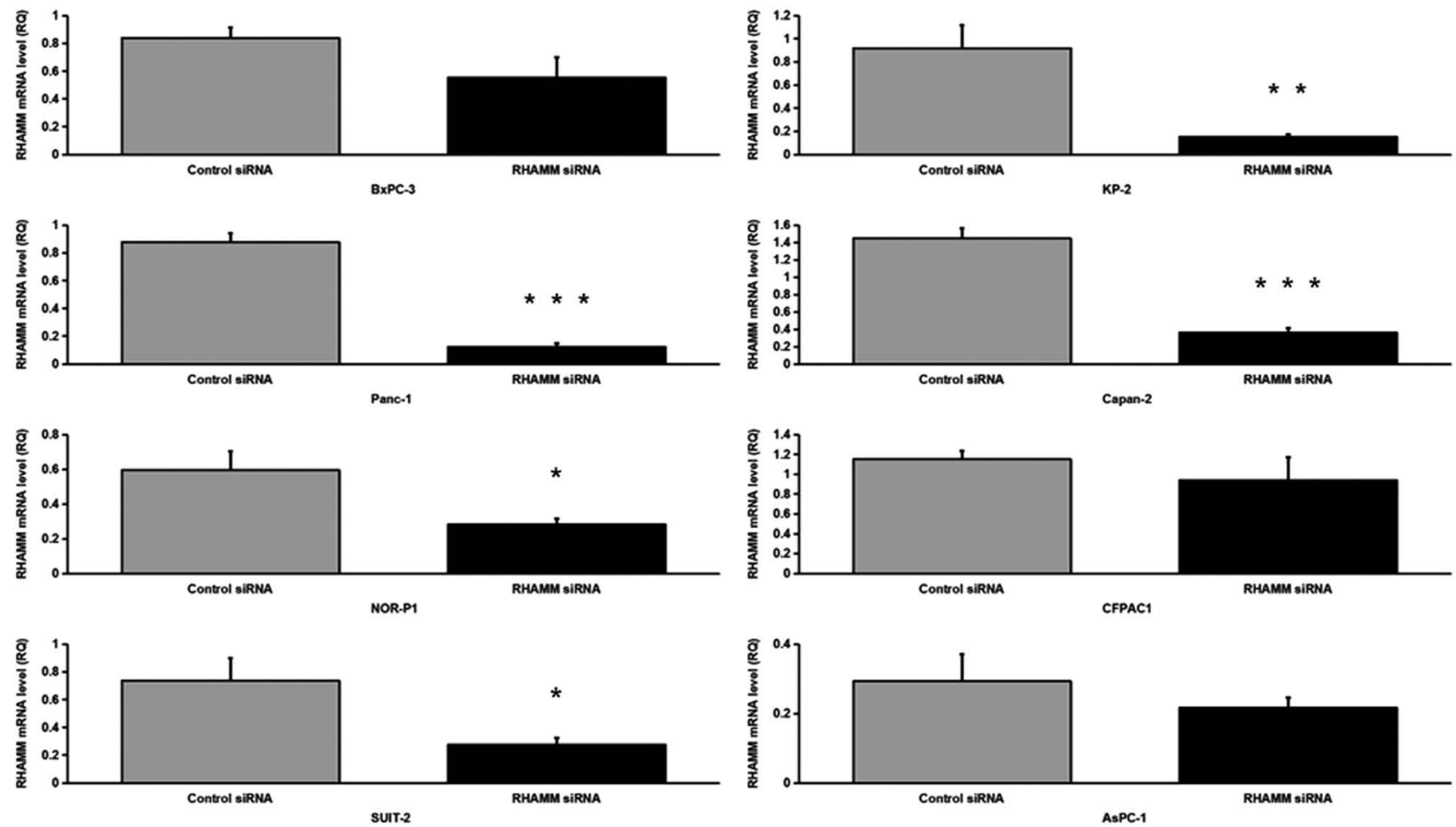

Figure 1. Changes in RHAMM mRNA expression in eight PDAC cell lines transfected with siRNA targeting RHAMM. Transfection of PDAC cell lines with $100 \mathrm{nM}$ siRNA targeting RHAMM resulted in 18-86\% knockdown of RHAMM mRNA expression. Data are presented as the mean \pm SD of three replicates. ${ }^{*} \mathrm{P}<0.05 ;{ }^{* *} \mathrm{P}<0.01 ;{ }^{* * *} \mathrm{P}<0.001$ (independent-samples t-test). RHAMM, receptor for hyaluronic acid-mediated motility; siRNA, small interfering RNA; PDAC, pancreatic ductal adenocarcinoma; $R Q$, relative quantity.

air-dried. The number of migrating cells was counted in six randomly selected fields (magnification, x400) using a light microscope.

ELISA for determination of HA concentration. The untreated, RHAMM siRNA-, 4-MU- and TPA-treated cells were cultured in the medium at $37^{\circ} \mathrm{C}$ for $48 \mathrm{~h}$, while the monoculture and co-culture cells were cultured in the medium at $37^{\circ} \mathrm{C}$ for $72 \mathrm{~h}$, after which the medium was collected and clarified by centrifugation at room temperature $(1,000 \mathrm{x}$ for $15 \mathrm{~min})$. The supernatant fraction was aliquoted and stored at $-80^{\circ} \mathrm{C}$ until further use. HA concentrations in cell culture medium and thawed pancreatic tissue extracts were determined using an HA ELISA kit (cat. no. DHYALO; R\&D Systems, Inc.) as previously described (11).
SUIT-2-based models. A total of $\sim 4 \times 10^{5}$ SUIT-2 cells were maintained in $2 \mathrm{ml}$ serum-free medium at $37^{\circ} \mathrm{C}$ for $12 \mathrm{~h}$. Subsequently, the medium was replaced with fresh medium containing $1 \%$ FBS with or without 4 -MU $(1,000 \mu \mathrm{M})$ or TPA $(100 \mathrm{ng} / \mathrm{ml})$ at $37^{\circ} \mathrm{C}$ for $48 \mathrm{~h}$. SUIT-2 cells $\left(2 \times 10^{5} / \mathrm{ml}\right)$ in $1 \mathrm{ml}$ serum-free medium were seeded in the upper chamber (High Density, Translucent PET Membrane 6-well insert, $0.4-\mu \mathrm{m}$ pore size; BD Biosciences) and $3 \mathrm{ml}$ serum-free medium was added into the lower chamber as monoculture. Simultaneously, sk-f 2 cells $\left(1 \times 10^{5} / \mathrm{ml}\right)$ in $3 \mathrm{ml}$ serum-free medium were seeded in the lower chamber for co-culture with SUIT-2 cells at $37^{\circ} \mathrm{C}$ for $72 \mathrm{~h}$. For all samples, the supernatant was collected and clarified via centrifugation at room temperature (1,000 x g for $15 \mathrm{~min})$, and RNA was extracted as previously described (8). 
Control siRNA
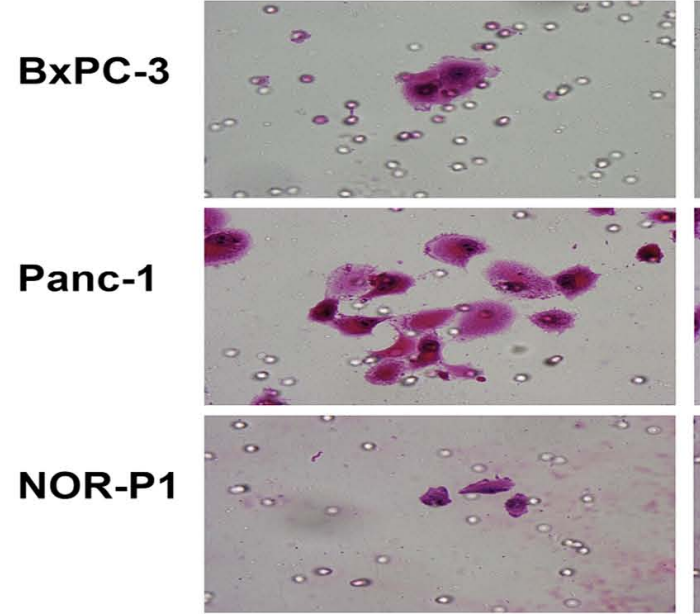

\section{SUIT-2}

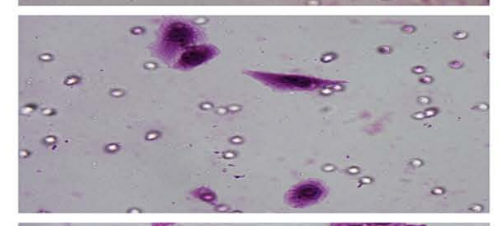

KP-2

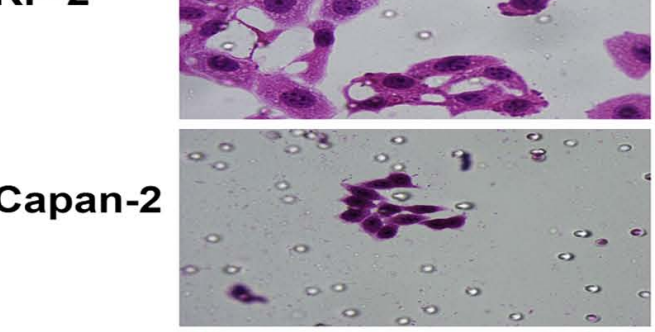

CFPAC1

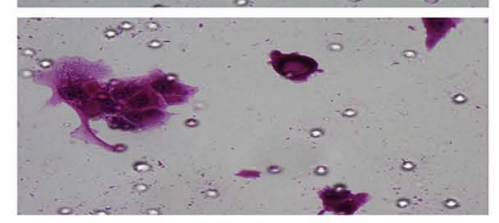

AsPC-1

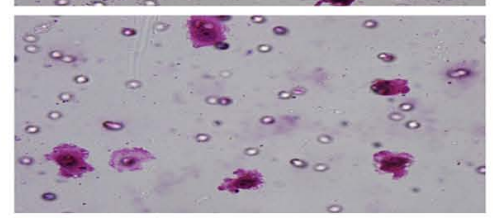

RHAMM SIRNA
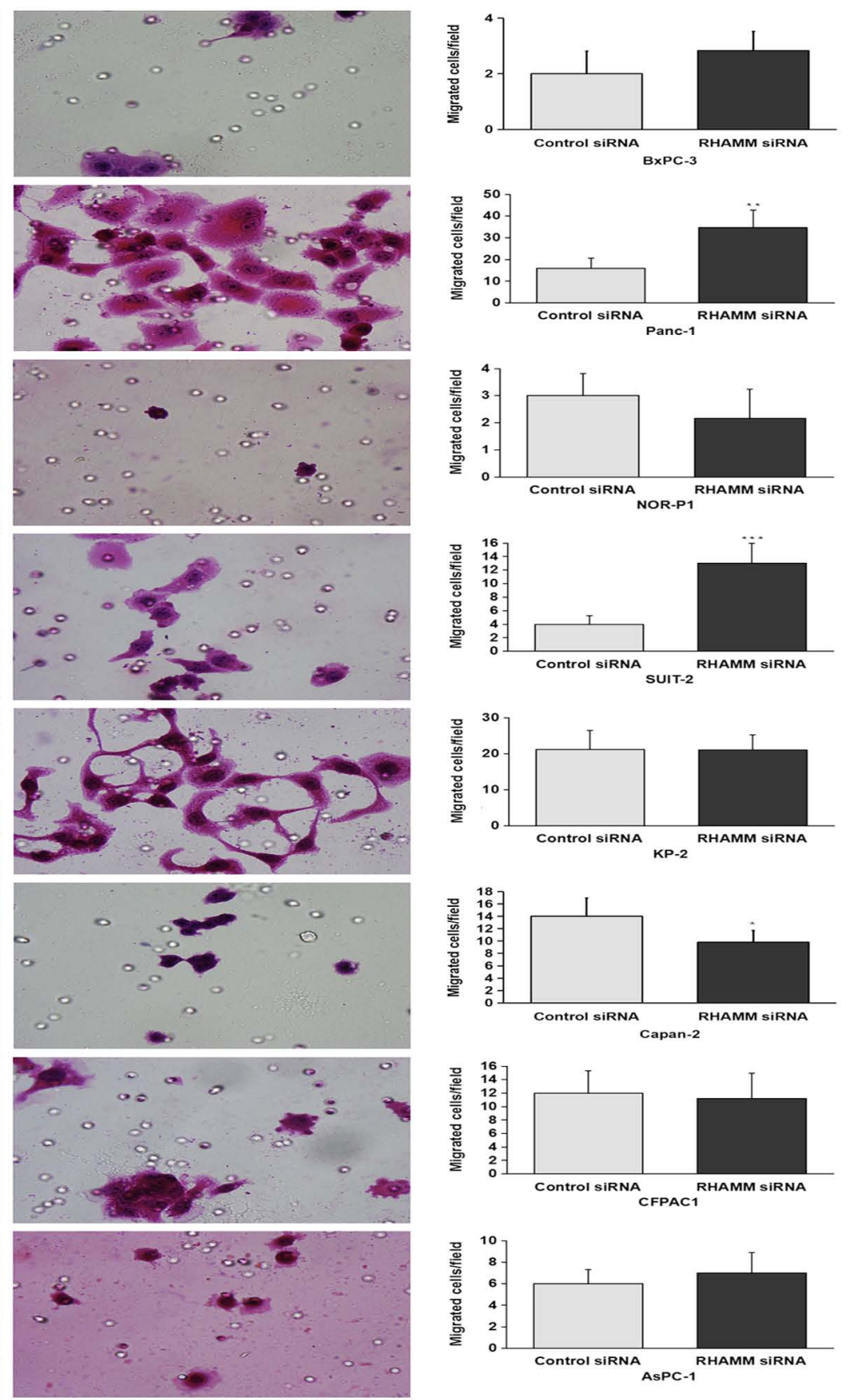

Figure 2. Changes in migration of eight pancreatic ductal adenocarcinoma cell lines following knockdown of RHAMM analyzed using Transwell migration assays (magnification, x400). The numbers of migrating cells following knockdown of RHAMM were significantly increased in two cell lines (Panc-1 and SUIT-2), significantly decreased in Capan-2 cells and remained unchanged in the other cell lines. Data are presented as the mean \pm SD of six replicates. ${ }^{*} \mathrm{P}<0.05 ;{ }^{* *} \mathrm{P}<0.01 ;{ }^{* * *} \mathrm{P}<0.001$ (independent-samples t-test). RHAMM, receptor for hyaluronic acid-mediated motility; siRNA, small interfering RNA.

Statistical analysis. Data are presented as the mean \pm SD $(n=3$ or $n=6)$. All statistical analyses were performed using SPSS statistical software (v21.0; IBM Corp.). Differences in RHAMM mRNA expression, migrating cell number and HA production between untreated and treated groups were compared using an independent-samples t-test. Differences in HAS1-3 and HYAL1-3 mRNA expression between untreated and treated groups were compared using an independent-samples t-test (for individual cell lines) and the Mann-Whitney U test (when combining the expression levels of all cell lines). Spearman's rank correlation coefficient was used to assess the correlation between RHAMM mRNA expression and HA concentration in PDAC cell lines and tissues, and the NOR-P1 sample was used as a reference. $\mathrm{P}<0.05$ was considered to indicate a statistically significant difference.

\section{Results}

Effects of RHAMM-knockdown on migration and HA production of PDAC cells. siRNA was used to knock down RHAMM expression in eight PDAC cell lines for $24 \mathrm{~h}$, and the collected cells $\left(2 \times 10^{5} / \mathrm{ml}\right)$ were seeded in $2 \mathrm{ml}$ medium with $1 \%$ FBS for $48 \mathrm{~h}$. RT-qPCR revealed that transfection of PDAC cell lines with $100 \mathrm{nM}$ siRNA targeting RHAMM resulted in $18-86 \%$ 

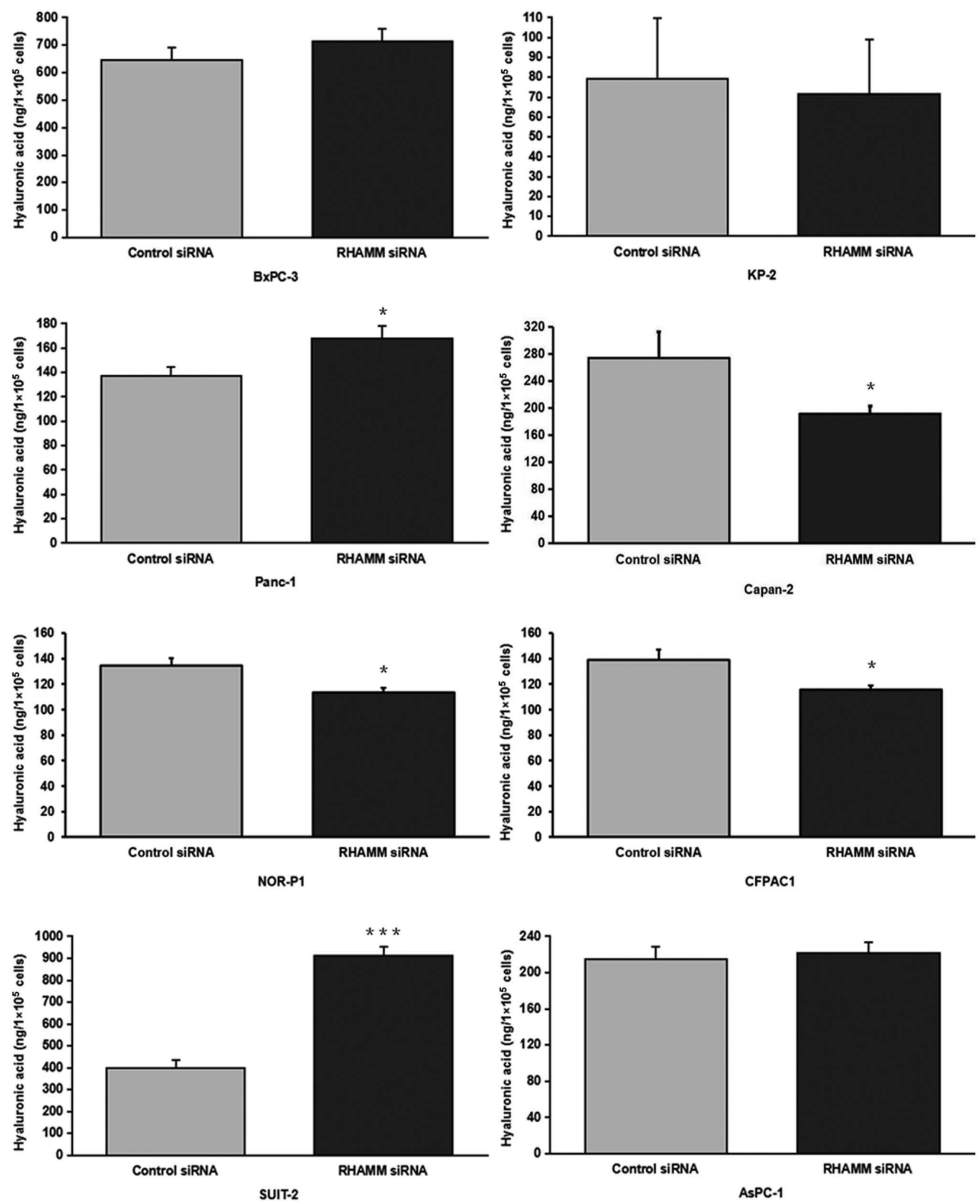

Figure 3. Changes in HA production in eight pancreatic ductal adenocarcinoma cell lines following knockdown of RHAMM- analyzed via ELISA. HA production was significantly increased in two cell lines (Panc-1 and SUIT-2), significantly decreased in three cell lines (NOR-P1, CFPAC1 and Capan-2) and remained unchanged in the other cell lines following RHAMM-knockdown. Data are presented as the mean \pm SD of three replicates. ${ }^{*} \mathrm{P}<0.05$; ${ }^{* * * *} \mathrm{P}<0.001$ (independent-samples t-test). HA, hyaluronic acid; RHAMM, receptor for hyaluronic acid-mediated motility; siRNA, small interfering RNA.

knockdown of RHAMM mRNA expression. The transfection of five PDAC cell lines (Panc-1, NOR-P1, SUIT-2, KP-2 and Capan-2) with siRNA targeting RHAMM resulted in a significant decrease in RHAMM mRNA expression compared with control siRNA-treated cell lines (Fig. 1). RHAMM-knockdown had no significant effects on cell viability, as assessed using a TBDE test (Fig. S1).

In response to RHAMM-knockdown, the number of migrating cells was significantly increased in two cell lines (Panc-1 and SUIT-2) and significantly decreased in Capan-2 

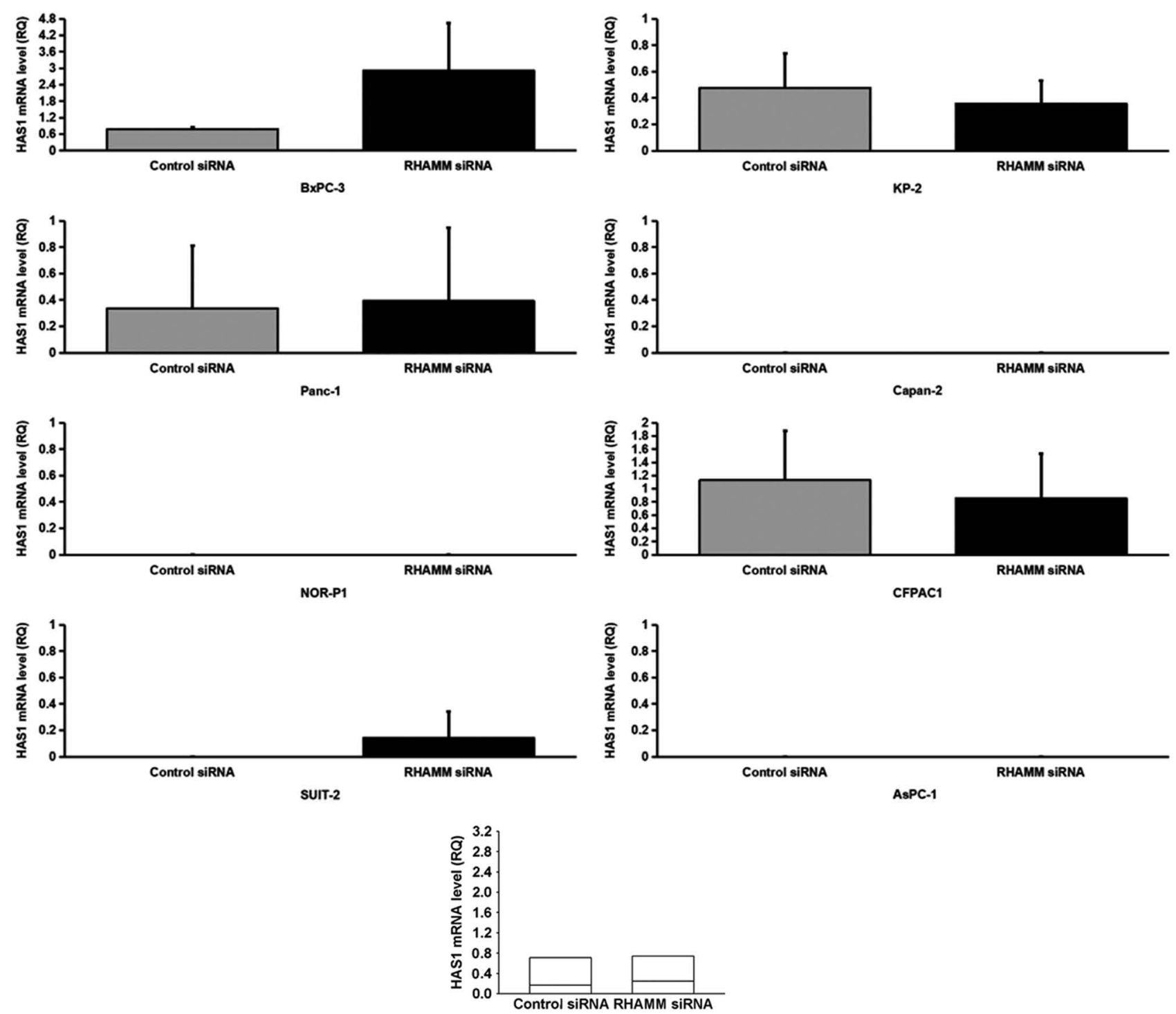

Figure 4. Changes in HAS1 mRNA expression in eight pancreatic ductal adenocarcinoma cell lines following treatment with siRNA targeting RHAMM. Data are presented as the mean $\pm \mathrm{SD}$ of three replicates. The white boxes at the bottom are a comprehensive representation of HAS1 mRNA expression in all cell lines, with the data presented as the median and interquartile range, revealing that HAS1 mRNA expression was not significantly changed following treatment. HAS1, hyaluronan synthase 1; RHAMM, receptor for hyaluronic acid-mediated motility; siRNA, small interfering RNA; RQ, relative quantity.

cells, while no significant difference was observed in the remaining cell lines (NOR-P1, BxPC-3, AsPC-1, CFPAC1 and KP-2; Fig. 2) compared with control siRNA-treated groups. Furthermore, HA production was significantly increased in two cell lines (Panc-1 and SUIT-2) and significantly decreased in three cell lines (NOR-P1, CFPAC1 and Capan-2), while no significant differences were observed in KP-2, BxPC-3 and AsPC-1 cell lines compared with control-siRNA treated groups (Fig. 3).

To elucidate the mechanism underlying HA modulation via RHAMM-knockdown, the mRNA expression levels of HA-synthesizing enzymes, HAS1-3 (Figs. 4-6), and HA-degrading enzymes, HYAL1-3 (Figs. 7-9), in PDAC cells were analyzed using RT-qPCR. RHAMM-knockdown led to a significantly increased production of HAS2 mRNA expression in six cell lines (BxPC-3, Panc-1, SUIT-2, KP-2, CFPAC1 and AsPC-1; Fig. 5), HYAL1 mRNA expression in five cell lines (Panc-1, NOR-P1, Capan-2, CFPAC1 and
AsPC-1; Fig. 7), HYAL2 mRNA expression in three cell lines (NOR-P1, Capan-2 and AsPC-1; Fig. 8) and HYAL3 mRNA expression in two cell lines (Panc-1 and AsPC-1; Fig. 9), compared with the control siRNA-treated groups. As aforementioned, RHAMM-knockdown led to increased production of HA in two cell lines (Panc-1 and SUIT-2), which may have been induced by a significant increase in combined HAS2 mRNA expression compared with the control siRNA-treated groups (Fig. 5), and decreased production of HA in three cell lines (NOR-P1, CFPAC1 and Capan-2), which may have been induced by significantly increased combined HYAL1 mRNA expression compared with the control siRNA-treated groups (Fig. 7).

Correlation between RHAMM mRNA expression and HA concentration. The present study hypothesized that there may be a correlation between RHAMM mRNA expression and HA concentration. To test this, RHAMM mRNA expression and 

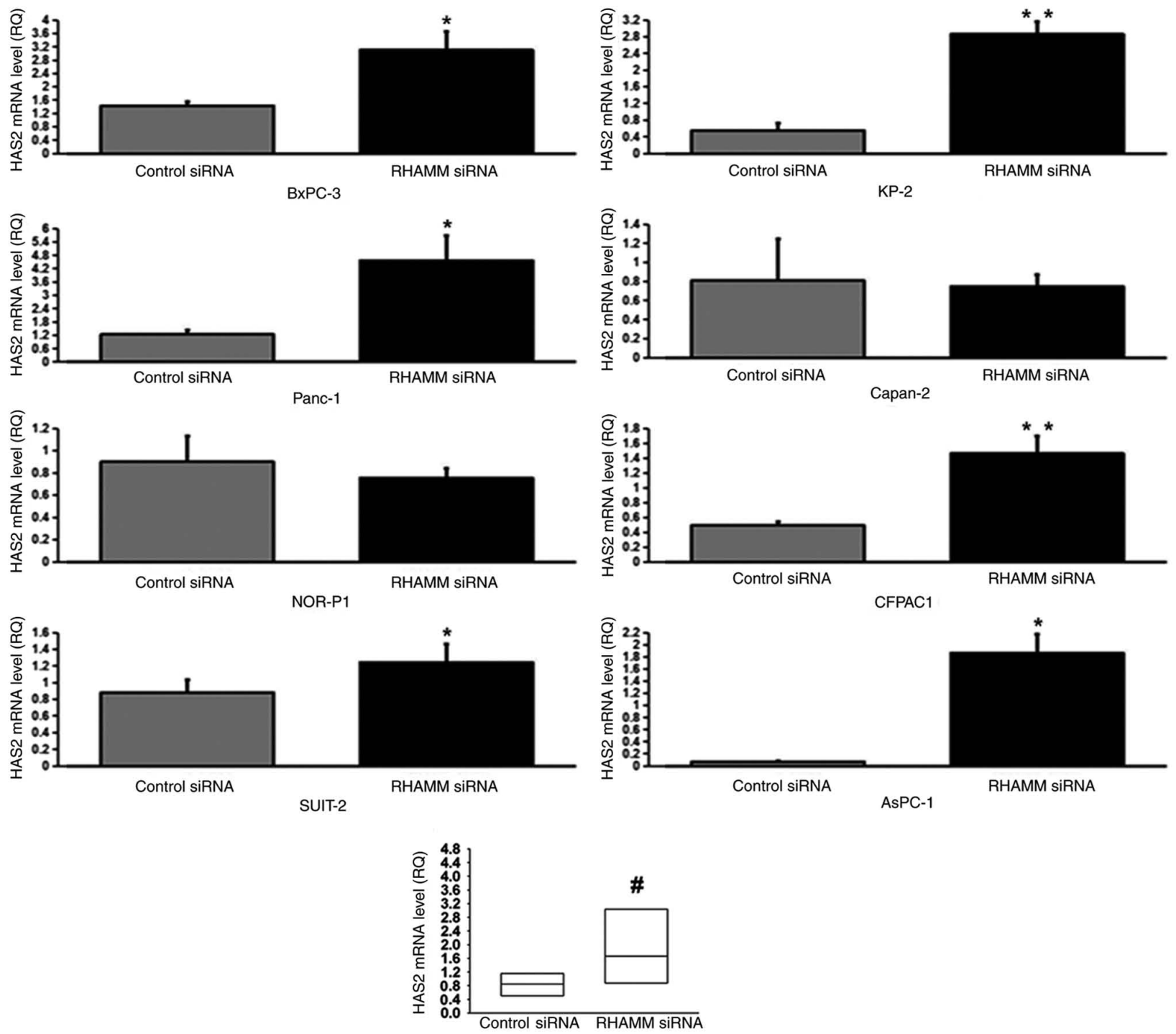

Figure 5. Changes in HAS2 mRNA expression in eight pancreatic ductal adenocarcinoma cell lines following treatment with siRNA targeting RHAMM. Data are presented as the mean \pm SD of three replicates. The white boxes at the bottom are a comprehensive representation of HAS 2 mRNA expression in all cell lines, with the data presented as the median and interquartile range, revealing that HAS2 mRNA expression was significantly increased following treatment. ${ }^{*} \mathrm{P}<0.05 ;{ }^{* *} \mathrm{P}<0.01$ (independent-samples t-test), ${ }^{*} \mathrm{P}<0.05$ (Mann-Whitney U test). HAS2, hyaluronan synthase 2; RHAMM, receptor for hyaluronic acid-mediated motility; siRNA, small interfering RNA; RQ, relative quantity.

HA concentration were examined in eight PDAC cell lines and tissues from 20 patients with PDAC. Fig. 10A shows a significant linear negative correlation between RHAMM mRNA expression and HA concentration in PDAC cell lines $(r=-0.738$; $\mathrm{P}=0.037$ ). Additionally, Fig. 10B shows a significant linear negative correlation between RHAMM mRNA expression and HA concentration in PDAC tissues $(\mathrm{r}=-0.759 ; \mathrm{P}<0.0001)$.

SUIT-2 cells were selected to further confirm the negative correlation between RHAMM mRNA expression and HA concentration, since this cell line exhibits low mRNA expression levels of RHAMM (8) and high HA production (12). HA concentration was significantly decreased $(\mathrm{P}<0.0001)$ and RHAMM mRNA expression levels were significantly increased $(\mathrm{P}=0.006)$ when SUIT-2 cells were treated with an HA inhibitor (4-MU; 1,000 $\mu \mathrm{M}$ ) compared with untreated cells (Fig. 11A). By contrast, HA concentration was significantly increased $(\mathrm{P}=0.012)$ and RHAMM mRNA expression levels were significantly decreased $(\mathrm{P}=0.049)$ when SUIT-2 cells were treated with an HA stimulator (TPA; $100 \mathrm{ng} / \mathrm{ml}$ ) compared with untreated cells (Fig. 11B). 4-MU and TPA had no significant effects on SUIT-2 cell viability (data not shown) when applied at the same concentrations used in a previous study (11). Additionally, HA concentration was significantly increased $(\mathrm{P}<0.0001)$ and RHAMM mRNA expression levels were significantly decreased $(\mathrm{P}<0.0001)$ when SUIT-2 cells were co-cultured with primary fibroblasts compared with monoculture (Fig. 11C).

\section{Discussion}

In the present study, the effects of RHAMM on PDAC cell migration were investigated using RHAMM-knockdown. In contrast to our hypothesis that cell migration would be inhibited, RHAMM-knockdown resulted in a significantly increased number of migrating cells in two cell lines (Panc-1 and SUIT-2) and a significantly decreased number of 

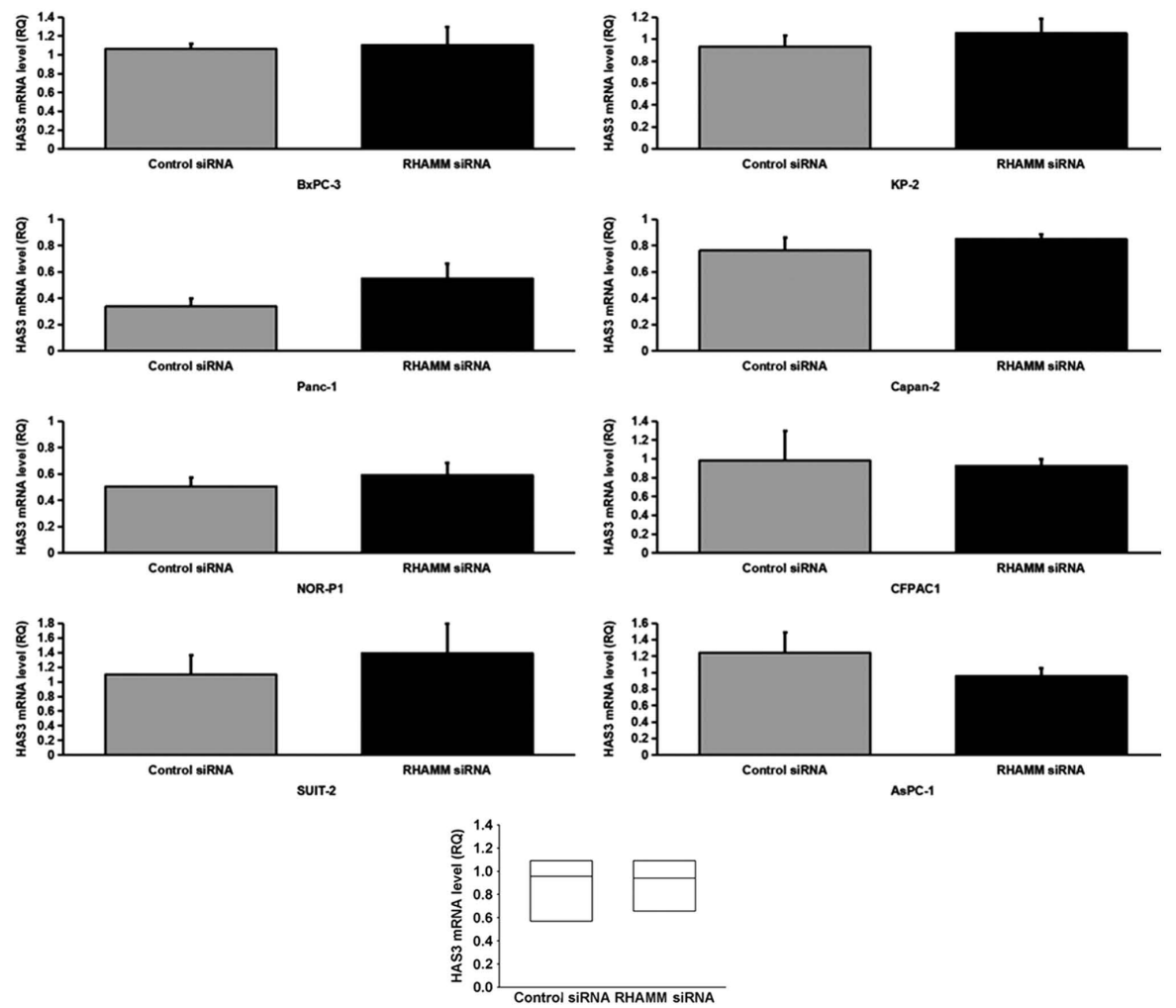

Figure 6. Changes in HAS3 mRNA expression in eight pancreatic ductal adenocarcinoma cell lines following treatment with siRNA targeting RHAMM. Data are presented as the mean \pm SD of three replicates. The white boxes at the bottom are a comprehensive representation of HAS3 mRNA expression in all cell lines, with the data presented as the median and interquartile range, revealing that HAS3 mRNA expression was not significantly changed following treatment. HAS3, hyaluronan synthase 3; RHAMM, receptor for hyaluronic acid-mediated motility; siRNA, small interfering RNA; RQ, relative quantity.
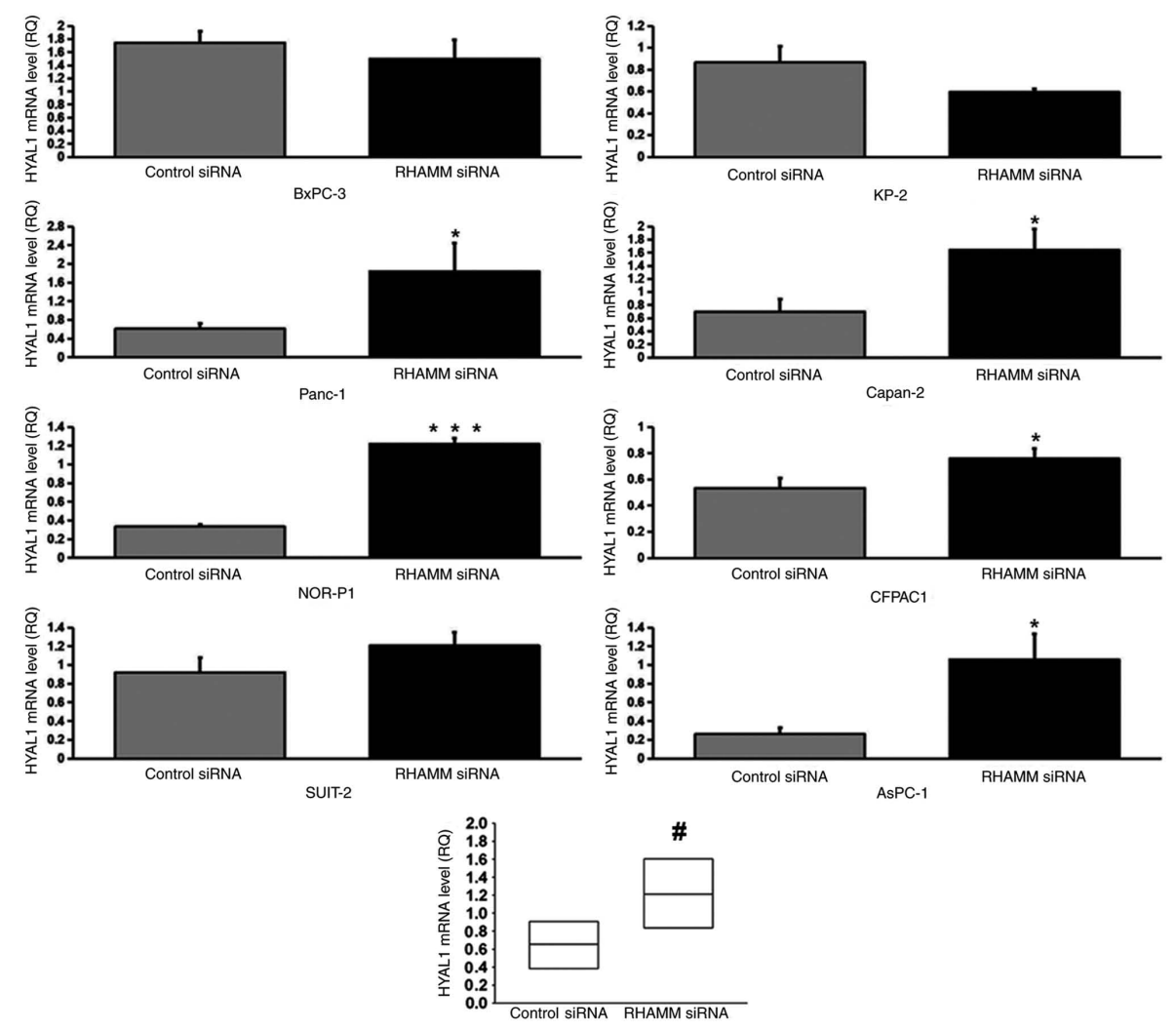

Figure 7. Changes in HYAL1 mRNA expression in eight pancreatic ductal adenocarcinoma cell lines following treatment with siRNA targeting RHAMM. Data are presented as the mean \pm SD of three replicates. The white boxes at the bottom are a comprehensive representation of HYAL1 mRNA expression in all cell lines, with the data presented as the median and interquartile range, revealing that HYAL1 expression was significantly increased following treatment. ${ }^{*} \mathrm{P}<0.05 ;{ }^{* * * *} \mathrm{P}<0.001$ (independent-samples t-test), ${ }^{\prime \prime} \mathrm{P}<0.05$ (Mann-Whitney $\mathrm{U}$ test). HYAL1, hyaluronidase 1; RHAMM, receptor for hyaluronic acid-mediated motility; siRNA, small interfering RNA; RQ, relative quantity. 

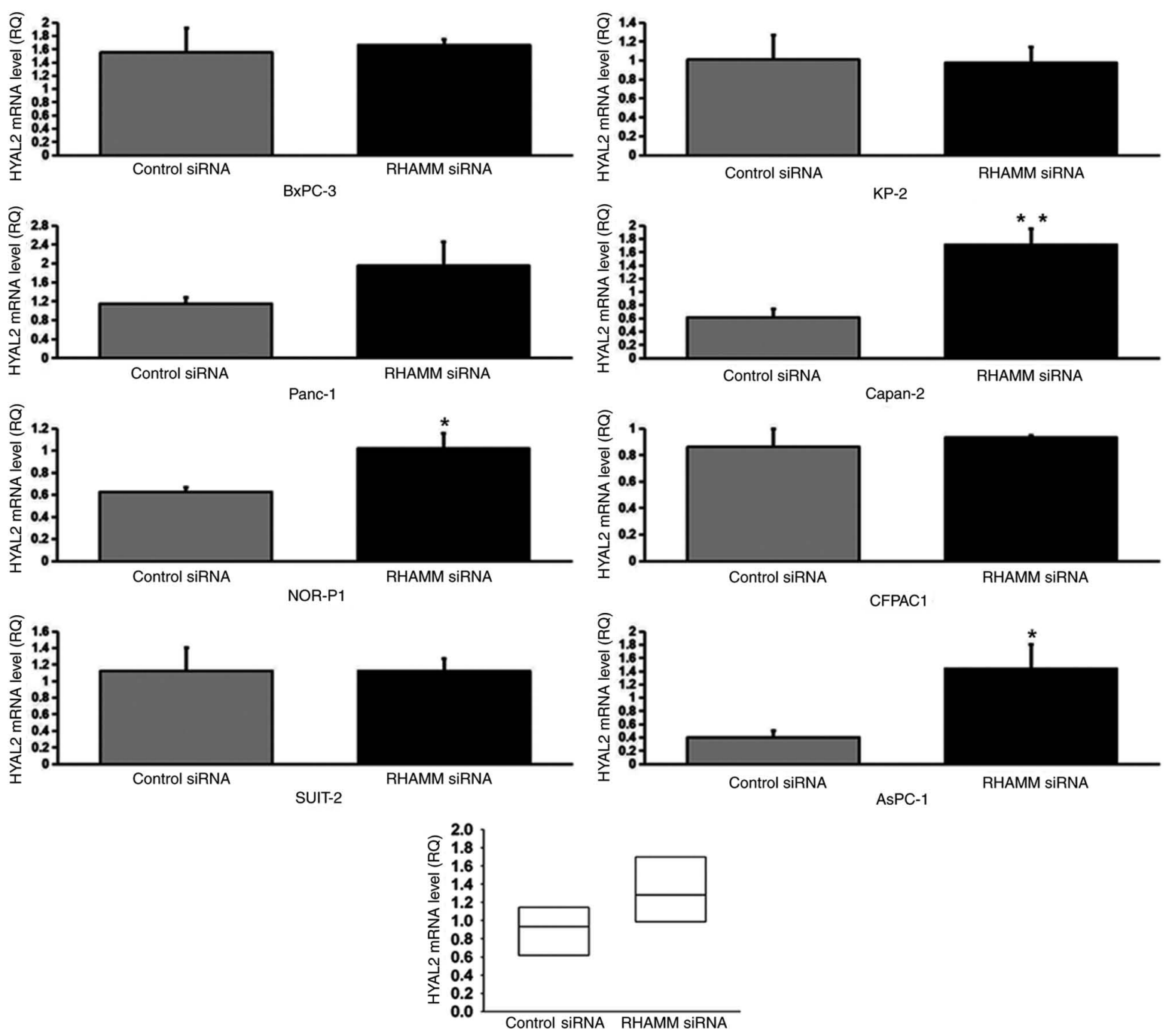

Figure 8. Changes in HYAL2 mRNA expression in eight pancreatic ductal adenocarcinoma cell lines following treatment with siRNA targeting RHAMM. Data are presented as the mean \pm SD of three replicates. The white boxes at the bottom are a comprehensive representation of HYAL2 mRNA expression in all cell lines, with the data presented as the median and interquartile range, revealing that HYAL2 mRNA expression was not significantly changed following treatment. ${ }^{*} \mathrm{P}<0.05 ;{ }^{* *} \mathrm{P}<0.01$ (independent-samples t-test). HYAL2, hyaluronidase 2; RHAMM, receptor for hyaluronic acid-mediated motility; siRNA, small interfering RNA; RQ, relative quantity.

migrating cells in Capan-2 cells, while no significant differences were observed in the remaining cell lines (NOR-P1, BxPC-3, AsPC-1, CFPAC1 and KP-2) compared with untreated groups. Several human PDAC cell lines (PaTu 8902, PaTu II, PaTu 8988s, PaTu 8988t and HPAF) synthesize and secrete HA, and in human primary pancreatic carcinomas, the highest level of HA is detected between the tumor mass and normal tissue (13). This suggests that HA may promote tumor invasion (14-17). In our previous study (12), it was demonstrated that HA significantly increases PDAC cell migration compared with untreated groups. Therefore, it was suspected that RHAMM-knockdown may lead to increased HA production, resulting in the aforementioned phenomena. In the present study, ELISA and RT-qPCR assays suggested that HA production in two cell lines (Panc-1 and SUIT-2) may have been increased in a manner dependent on increased HAS2 mRNA expression, while HA production in three other cell lines (NOR-P1, CFPAC1 and Capan-2) may have been decreased in a manner dependent on increased HYAL1 mRNA expression. Therefore, there is reason to hypothesize that RHAMM may regulate PDAC cell migration via changes in HA production.

The RHAMM gene is localized on human chromosome band 5q33.2 and contains 18 exons (18). RHAMM mRNA expression is controlled by its promoter at the transcriptional level in a cell cycle-dependent manner, and RHAMM protein levels follow mRNA expression levels in the early phases of the cell cycle (18). However, RHAMM protein levels peak during the $S$ phase and decrease before the highest RHAMM mRNA expression level is reached at the $G_{2} / M$ phase (18). Furthermore, RHAMM mRNA and protein levels are suppressed by p53 $(18,19)$. Lin et al $(20)$ demonstrated that the androgen receptor regulates RHAMM expression. In the present study, RHAMM mRNA expression and HA concentration were measured in PDAC cell lines, tissues and SUIT-2-based models, revealing that RHAMM mRNA expression was significantly negatively correlated with HA concentration. To the best of our knowledge, the present study was the first to demonstrate that HA may be negatively correlated with RHAMM mRNA expression. 

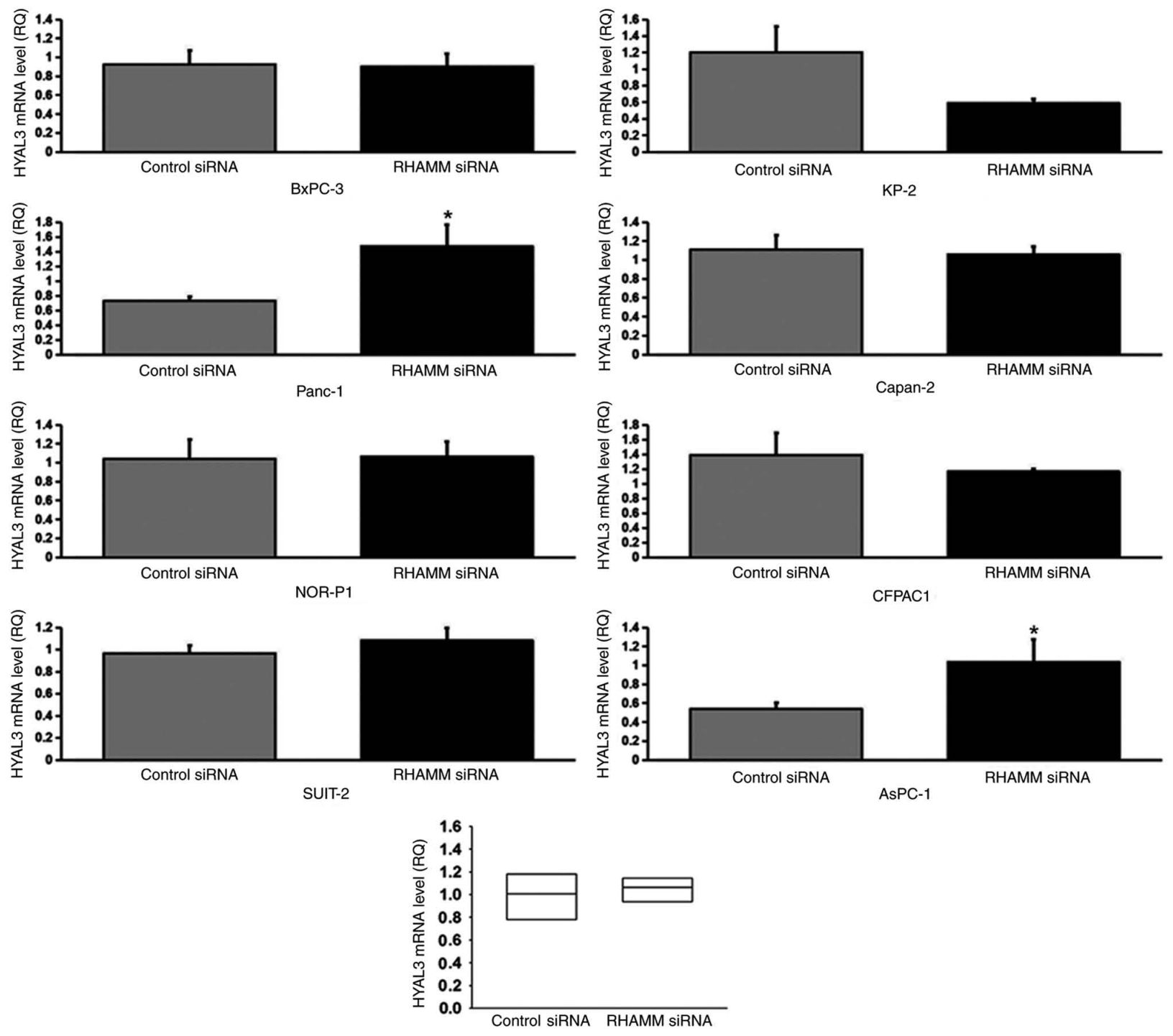

Figure 9. Changes in HYAL3 mRNA expression in eight pancreatic ductal adenocarcinoma cell lines after treatment with siRNA targeting for RHAMM Data are presented as the mean \pm SD of three replicates. The white boxes at the bottom are a comprehensive representation of HYAL 3 mRNA expression in all cell lines, with the data presented as the median and interquartile range, revealing that HYAL3 mRNA expression was not significantly changed following treatment. "P<0.05 (independent-samples t-test). HYAL3, hyaluronidase 3; RHAMM, receptor for hyaluronic acid-mediated motility; siRNA, small interfering RNA; RQ, relative quantity.
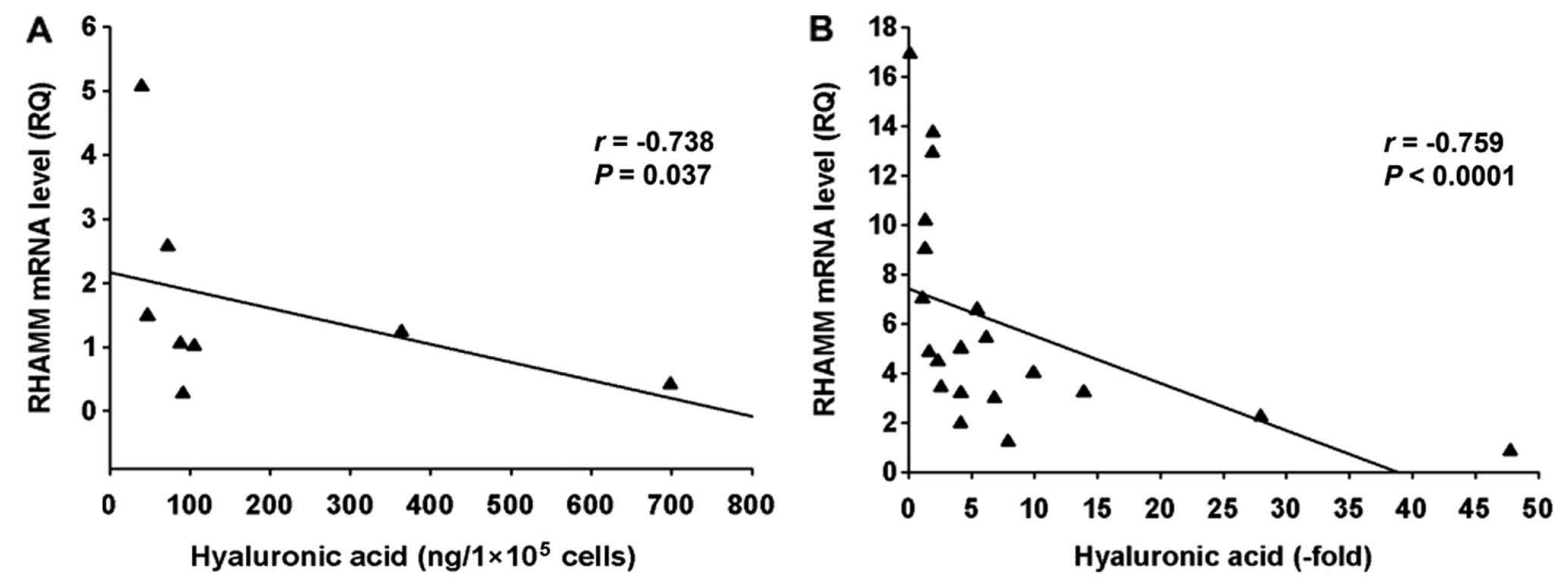

Figure 10. Correlation between RHAMM mRNA expression and HA concentration. (A) Spearman's rank correlation analysis revealing a significant linear negative correlation between RHAMM mRNA expression and HA concentration in eight pancreatic ductal adenocarcinoma cell lines. The NOR-P1 sample was used as the reference. (B) Significant linear negative correlation between RHAMM mRNA expression and HA concentration in tissues from 20 patients with pancreatic ductal adenocarcinoma. The adjacent non-tumor tissues were used as a reference. The $\mathrm{x}$-axis indicates the fold change in HA concentration in cancer tissues compared with that in normal tissues. HA, hyaluronic acid; RHAMM, receptor for HA-mediated motility; RQ, relative quantity. 
A

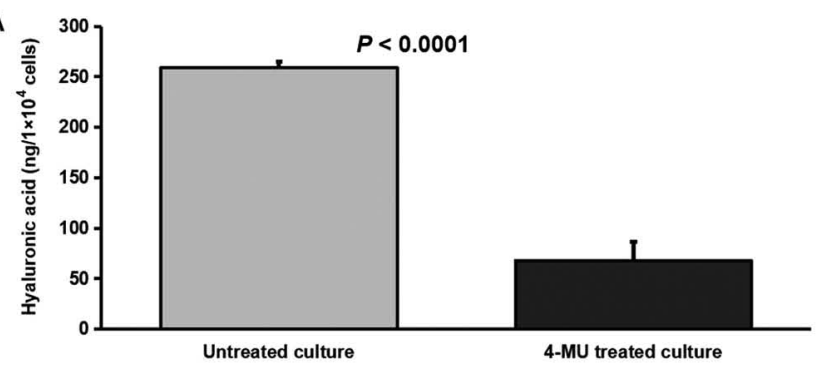

B

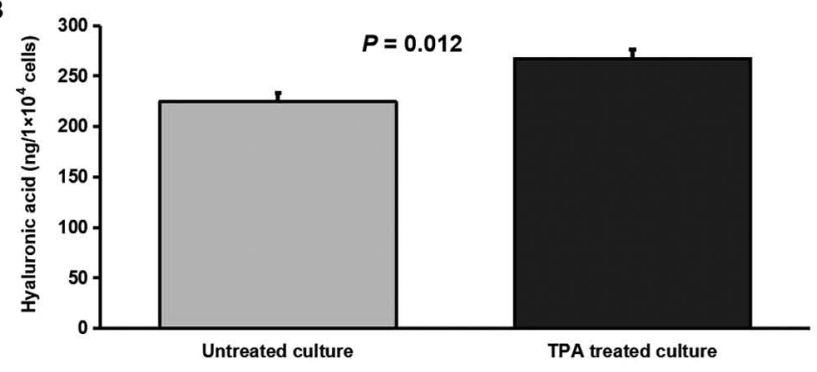

C

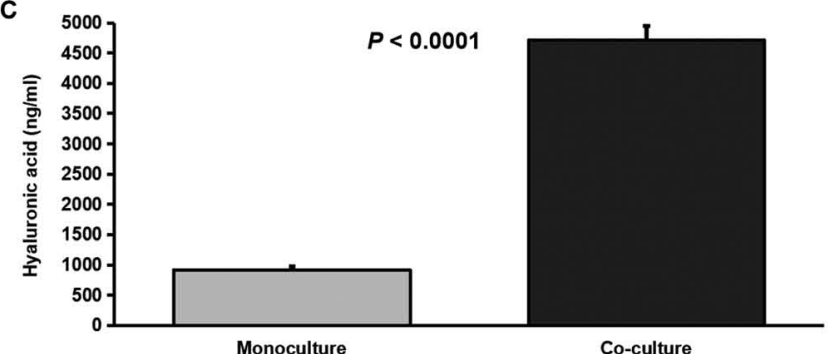

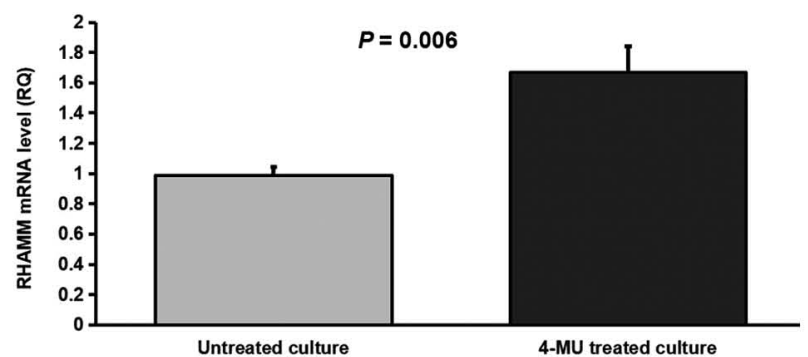
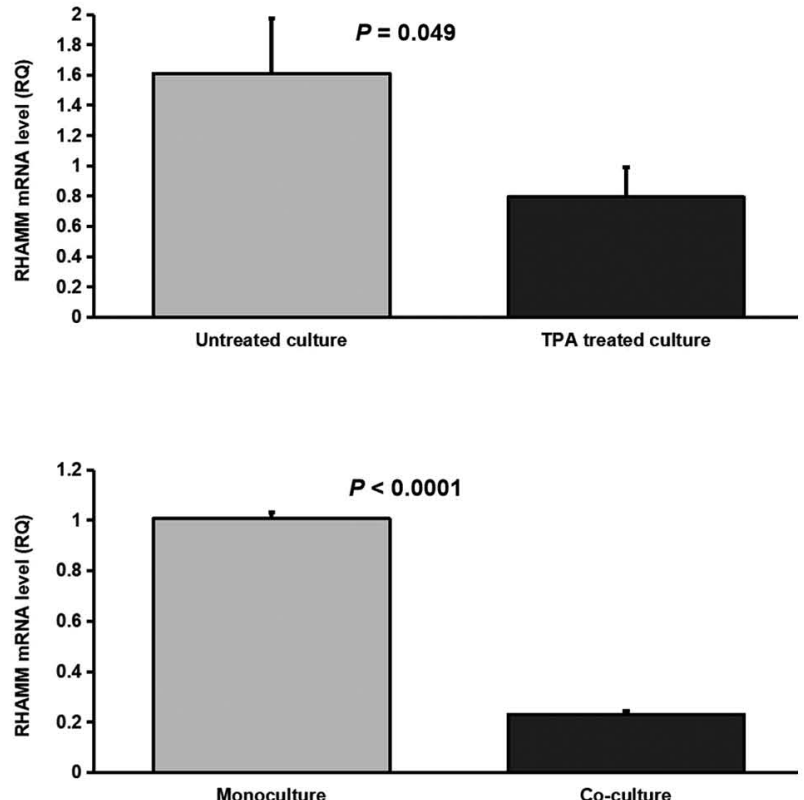

Figure 11. SUIT-2-based models proved that RHAMM mRNA expression is significantly and negatively associated with HA concentration. (A) HA concentration was significantly decreased and RHAMM mRNA expression levels were significantly increased when SUIT-2 cells were treated with an HA inhibitor (4-MU; 1,000 $\mu \mathrm{M}$ ). (B) HA concentration was significantly increased and RHAMM mRNA expression levels were significantly decreased when SUIT-2 cells were treated with an HA stimulator (TPA; $100 \mathrm{ng} / \mathrm{ml})$. (C) HA concentration was significantly increased and RHAMM mRNA expression levels were significantly decreased when SUIT-2 cells were co-cultured with primary fibroblasts (sk-f2). An independent-samples t-test was used to analyze the data. Data are presented as the mean \pm SD of three replicates. 4-MU, 4-methylumbelliferone; TPA, 12-O-tetradecanoyl-phorbol-13-acetate; HA, hyaluronic acid; RHAMM, receptor for HA-mediated motility; RQ, relative quantity.

The present findings suggest a complex mechanism regulating RHAMM mRNA expression and HA synthesis in PDAC cells at the genetic level. There may be a negative correlation between RHAMM mRNA expression and HA production in a subset of PDAC cell lines. Future studies should confirm whether there is a negative correlation between RHAMM expression and HA production in PDAC cell lines and tissues at the protein level, and explore its mechanism in depth in order to provide a stronger scientific basis for the evaluation of the risk and benefit of a therapeutic strategy targeting RHAMM.

\section{Acknowledgements}

Not applicable.

\section{Funding}

The present study was supported by the Medical and Health Science and Technology Innovation Foundation of Jinshan District of Shanghai (grant no. 2018-3-23), the Intramural
Funding from Shanghai Public Health Clinical Center (grant no. KY-GW-2018-03), the Shanghai Municipal Committee for Health and Family Planning (grant no. 201740194), the Clinical Science and Technology Innovation Foundation of Shanghai Shenkang Hospital Development Center (grant no. SHDC12018112) and the National 13th Five-Year Grand Program on Key Infectious Disease Control (grant no. 2018ZX10302103-003).

\section{Availability of data and materials}

All data generated or analyzed during this study are included in this published article.

\section{Authors' contributions}

NS, YZ and XC conceived the experimental design. XC, SW, HY and HT performed the experiments. XC, SW, GS, LW, JZ, LS, HL and SR analyzed the data. XC, SW, NS and $\mathrm{YZ}$ wrote the paper. All authors read and approved the final manuscript. 


\section{Ethics approval and consent to participate}

The present study was approved by the Ethics Committee of the University of Occupational and Environmental Health (Kitakyushu, Japan), and written informed consent was obtained from all patients who approved the use of their tissues for unspecified research purposes.

\section{Patient consent for publication}

Not applicable.

\section{Competing interests}

The authors declare that they have no competing interests.

\section{References}

1. Siegel R, Naishadham D and Jemal A: Cancer statistics, 2013. CA Cancer J Clin 63: 11-30, 2013.

2. Hidalgo M: Pancreatic cancer. N Engl J Med 362: 1605-1617, 2010.

3. Bardeesy $\mathrm{N}$ and DePinho RA: Pancreatic cancer biology and genetics. Nat Rev Cancer 2: 897-909, 2002.

4. Mahadevan D and Von Hoff DD: Tumor-stroma interactions in pancreatic ductal adenocarcinoma. Mol Cancer Ther 6: 1186-1197, 2007.

5. Erkan M, Reiser-Erkan C, Michalski CW and Kleeff J: Tumor microenvironment and progression of pancreatic cancer. Exp Oncol 32: 128-131, 2010.

6. Schwertfeger KL, Cowman MK, Telmer PG, Turley EA and McCarthy JB: Hyaluronan, inflammation, and breast cancer progression. Front Immunol 6: 236, 2015.

7. Li XP, Zhang XW, Zheng LZ and Guo WJ: Expression of CD44 in pancreatic cancer and its significance. Int J Clin Exp Pathol 8: 6724-6731, 2015

8. Cheng XB, Sato N, Kohi S, Koga A and Hirata K: Receptor for hyaluronic acid-mediated motility is associated with poor survival in pancreatic ductal adenocarcinoma. J Cancer 6: 1093-1098, 2015.
9. Gust KM, Hofer MD, Perner SR, Kim R, Chinnaiyan AM, Varambally S, Moller P, Rinnab L, Rubin MA, Greiner J, et al: RHAMM (CD168) is overexpressed at the protein level and may constitute an immunogenic antigen in advanced prostate cancer disease. Neoplasia 11: 956-963, 2009.

10. Livak KJ and Schmittgen TD: Analysis of relative gene expression data using real-time quantitative PCR and the 2(-Delta Delta C(T)) method. Methods 25: 402-408, 2001.

11. Cheng XB, Sato N, Kohi S and Yamaguchi K: Prognostic impact of hyaluronan and its regulators in pancreatic ductal adenocarcinoma. PLoS One 8: e80765, 2013.

12. Cheng XB, Kohi S, Koga A, Hirata K and Sato N: Hyaluronan stimulates pancreatic cancer cell motility. Oncotarget 7 : 4829-4840, 2016.

13. Mahlbacher V, Sewing A, Elsasser HP and Kern HF: Hyaluronan is a secretory product of human pancreatic adenocarcinoma cells. Eur J Cell Biol 58: 28-34, 1992.

14. Fries H, Elsasser HP, Mahlbacher V, Neumann K and Kern HF: Localisation of hyaluronate (HA) in primary tumors and nude mouse xenografts of human pancreatic carcinomas using a biotinylated HA-binding protein. Virchows Arch 424: 7-12, 1994.

15. McBride WH and Bard JB: Hyaluronidase-sensitive halos around adherent cells. Their role in blocking lymphocyte-mediated cytolysis. J Exp Med 149: 507-515, 1979.

16. Suzuki Y, Nishida Y, Naruse T, Gemba T and Ishiguro N: Pericellular matrix formation alters the efficiency of intracellular uptake of oligonucleotides in osteosarcoma cells. J Surg Res 152: $148-156,2009$.

17. Toole BP: Hyaluronan-CD44 interactions in cancer: Paradoxes and possibilities. Clin Cancer Res 15: 7462-7468, 2009.

18. Sohr S and Engeland K: RHAMM is differentially expressed in the cell cycle and downregulated by the tumor suppressor $\mathrm{p} 53$. Cell cycle 7: 3448-3460, 2008.

19. Godar S and Weinberg RA: Filling the mosaic of p53 actions: P53 represses RHAMM expression. Cell cycle 7: 3479, 2008.

20. Lin SL, Chang D, Chiang A and Ying SY: Androgen receptor regulates CD168 expression and signaling in prostate cancer. Carcinogenesis 29: 282-290, 2008.

(i) (9) This work is licensed under a Creative Commons Attribution-NonCommercial-NoDerivatives 4.0 International (CC BY-NC-ND 4.0) License. 